Georgy K. Koshelev

Ph.D. in History of Arts,

Associate Professor, Art History and Humanities Department Moscow State Stroganov Academy of Industrial and Applied Arts e-mail: logomachia@mail.ru Moscow, Russia ORCID 0000-0003-4950-3891

ResearcherID AAH-2163-2020

Alexandra M. Spiridonova

Graduate student of the Art History and Humanities Department Moscow State Stroganov Academy of Industrial and Applied Arts e-mail: freaklt@yandex.ru Moscow, Russia

ORCID 0000-0003-2760-8553

ResearcherID AAH-2166-2020

DOI: 10.36340/2071-6818-2020-16-2-33-46

\title{
ALEXANDER MELAMID'S PORTRAITURE OF THE 2010s
}

Summary: The article focuses on a comprehensive study of Alexander Melamid's portraiture included in his first independent project after thirty years of collaborative creativity with Vitaly Komar. Throughout the entire thirty-year period of cooperation, the painters signed their works with the Komar and Melamid trademark making it difficult to determine the artists' individual characters. A detailed analysis of the solo works of the $60-70$ s, before the beginning of collaborative creativity, is presented; it helps us to detect individual traits in the works of the duet and to better identify the artists' personalities, to reconstruct the technical features of each artist's painting style.

In 2007, Alexander Melamid began creating a largescale series of paintings which would become his new conceptual line of creative work; later, in 2009, the artist developed and supplemented the series with portraits of Italian clergy and Russian oligarchs. Characteristic features of the Holy Hip Hop! portrait series, exhibited at the Detroit Museum of Modern Art in 2008, are studied in the article. The artist paid special attention to the psychological characters of the portrayed, the entire series is painted in one color scheme, within one scale. The pictorial series is an integral conceptual statement. The purely plastic qual- ities of the paintings fade into the background. They are not so important for Alexander Melamid - he uses academic painting as a tool to convey more accurately the psychology of the portrayed whom he treats with ironic interest. It is important to note that Alexander Melamid erases the line between the classical and the marginal art, just as Francois Millet did in his time.

The article succeeded in updating sociocultural issues with the help of contextual comparison with portraiture by Diego Velazquez and contemporary American artist Kehinde Wiley whose creative life has deeply integrated into the socio-political realities of the United States of the beginning of the $21^{\text {st }}$ century and the African-American cultural tradition. Kehinde Wiley is known for his realistic large-scale portrayals of African-Americans in poses borrowed from works of classical European painting of the $17-19^{\text {th }}$ centuries. The artist openly propagandizes, deliberately emphasizing the didactic function of his paintings. It is in the context of contemporaries' works and the political situation in the USA of the 2000-2010s that Alexander Melamid's work should be considered.

Keywords: Komar and Melamid, Social art, Alexander Melamid, Vitaly Komar, portraiture, Kehinde Wiley. 
The comprehension of the creative evolution of Alexander Melamid, who had collaborated with Vitaly Komar for more than thirty years, is the main objective of the scientific research in this article. Throughout the period of cooperation, the artists jointly signed their work, rarely giving comments on the division of responsibilities or the process of creating paintings. It is the analysis of the solo works of the $60-70$ s, before the beginning of collaborative creativity and the period from 2003, the year of the breakup of the group, that helps us detect individual features in the works of the duet and better identify the artists' personalities.

The period of artists' collaborative creativity began in the 1970s and there are not many of their early personal works since almost all of them were taken abroad. The canvases later returned to Russia; however, they are now in private collections. Their first exhibitions were held in the BlueBird Café. [1] One of the leading researchers of the artists' works, Kirill Svetlyakov, writes: "If one tries to distinguish between the approaches of Komar and Melamid, then we can assume that Komar was more interested in the psychology of styles whereas Melamid was interested in the psychology of perception" [2]. The painting Portrait of Albina (ill. 1), 1969, is one of the striking examples of Alexander Melamid's early painting. The work is made in the Alla Prima manner with ocherous primer shining through sharp cold strokes of the background, indicating knowledge of the classical technology of oil painting [3]. The image of the model interacts little with the viewer and the space around it. The composition is characterized by carelessness: the knees are cut off by the edge of the canvas, the hands are painted without detail. The image is psychologically pointed facial expression is gloomy and depressive which is emphasized by sharply defined eyelids. This is not admiration for human nature and the nature of being but rather a painful statement of facts of reality with a real possibility of quoting the images of A. Toulouse-Lautrec's Parisian degraded people, the images which, along with other few works of representatives of Western modern painting, were familiar to the Soviet audience thanks to the publishing of the Knowledge is Power magazine, the editors of which were regular visitors to exhibitions and concerts in the BlueBird Café [4]. Artistic techniques which have been manifested in the artist's individual manner since 2007 are present in the work Portrait of Albina. In the painting, there is no clearly defined horizon, the figure is floating in the air; a dense chord of restrained tones, which is dominated by deep brown and greenish shades, maintains the overall heavy mood of the canvas. It is to this formula of compositional narrative that Alexander Melamid would return after a thirty-year period of collaborative creativity. Later, the artist commented on his early works, calling them "'the period of absolute truth' in relation to the ironic games of the next decade" [5].

Alexander's portrait period began in 2006, three years after the breakup of the duet. At that time, Vitaliy Komar was following the path of a search for an internal national identity, return to childhood, reflection on the theme of collaborative creativity [6] whereas Alexander Melamid, after a three-year creative lull, began to lead a new conceptual pictorial line. In 2007, the artist began to paint a largescale series of rapper portraits. Then he turned his attention to the cardinals and ministers of the Italian monasteries, and after, in 2009, to portraits of Russian oligarchs. In 2010, all portrait series were united in the general concept of the Oh My God Exhibition, at the presentation of which the artist declared: "Being God, I am the creator of everything on earth including ordinary objects like rocks and stuff, so I try to cover all bases. What's important is that I create these people. They don't exist without me. I pick them up and I put them on a pedestal". [7]

Alexander Melamid comments on the turn in his work in the article by Zinovy Zinik: "At some point in my life, I thought about what to do next. Either to return to the nostalgic past - parents, childhood, memories or to go somewhere forward. But where? And then I realized that my son - he just went further, further from our common past, from Moscow as the Third Rome, from the problem of the East and the West, and so on". [8]. The artist's son, Denis Melamid, works for the world-famous label G-Unit as a sound producer and takes part in the production of video clips, his name appears as Dan "The Man" Melamid [9].

Melamid deliberately distances himself from the portrayed model, cultural differences and features of upbringing do not allow the artist to be deeply integrated into the new musical environment; he comments: "This is actually a cult of white children of rich parents. For them, rappers are a kind of fabulous ideal world. In childhood, we all dreamt, like Nabokov's boys, to escape to America. In a Russian forest in Kratovo. We fled to the forest like to America. This is a world of inconceivable freedom, 


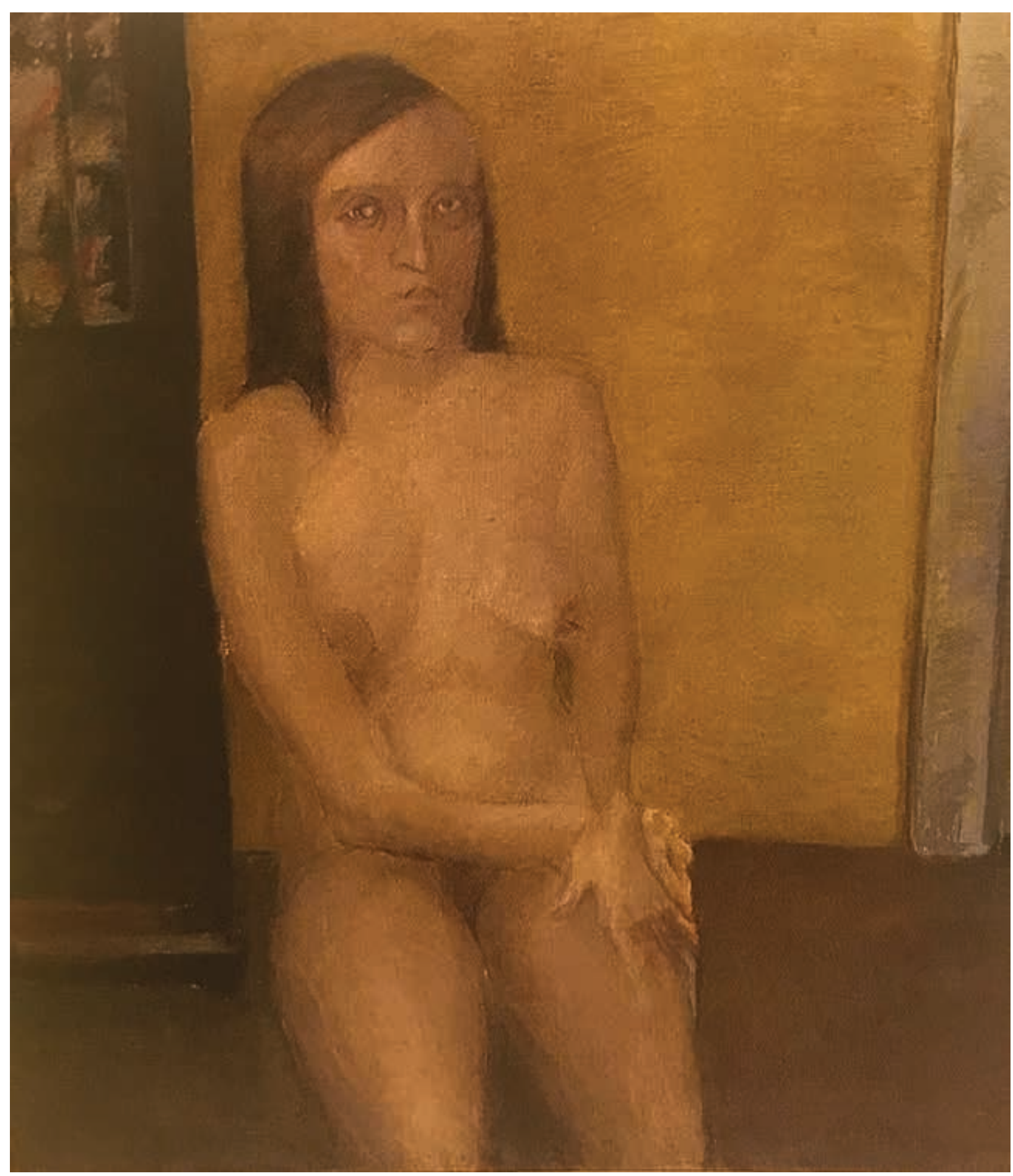

Ill. 1. "Portrait of Albina" by Alexander Melamid. 1969. Oil on canvas

where people are killed, of course, but you don't have to learn Latin and arithmetic or study the music of Bach and Tchaikovsky". However, then the artist adds to observe political correctness: "... rappers... are known to their fans, to their circle, and those do not understand anything in painting. But those who understand painting have hardly heard about rappers. I connect them together. This is a mysterious world. It is curious to me. What else is there in the world besides real curiosity? [10]".
For Alexander Melamid, who has been living in America since 1978, the social context created by racial conflicts, the rhetoric of tolerance, and the rise of nationalism is an everyday reality. Politics and culture penetrate life and work, just like Soviet visual propaganda constantly accompanied the life of a Soviet person in the youth of the artist. The creation of social art as a reaction and analysis of political propaganda was a creative statement of artists with the help of which they translated ideas 
into public consciousness. Melamid turned to the same technique when working on a series of portraits of rappers - they are not just a private artistic statement in which you can see self-citation of the series Nostalgic Socialist Realism, 1981-82, an homage to the Baroque painting of the $17^{\text {th }}$ centu$r y$, or direct imitation of a series of dwarfs and buffoons by Diego Velazquez of the 1630s-40s. This painting cannot exist without the context of the artistic works of Melamid's contemporaries, whose art is more politicized.

It is difficult not to compare the portraiture of Alexander Melamid with the works of New York-based Nigerian-American artist Kehinde Wiley known for his realistic large-scale portrayals of African-Americans in poses borrowed from classical European paintings of the $17-19^{\text {th }}$ century. Wiley is known for his decorative technique - realistically interpreted models are always against the background richly decorated with floral ornaments based on the motives of the great styles of the past: Renaissance, Baroque, Empire style. Rumors of War, a series of Wylie's paintings of 2006-07 in which the artist "transfers people to the contexts of military glory" [11], is of most interest to us since it chronologically coincides with the beginning of Alexander Melamid's portrait period. Napoleon at the Saint-Bernard Pass, 1801, the famous painting by the largest representative of French painting, Jacques-Louis David, who worked in the neoclassical style, was the prototype of one of Kehinde Wiley's paintings. [12] Kehinde Wiley categorically expresses his position on the interaction of African American and European art: "Art and violence have for an eternity held a strong narrative grip with each other. Rumors of War attempts to use the language of equestrian portraiture to both embrace and subsume the fetishization of state violence... I believe that when dealing with a troubled past and arguably a beautiful future, artists should use every tool in their wheelhouse. What I try to do is I say yes to certain aspects of history. And I say no to others". [13].

Wiley's painting Napoleon Leading the Army over the Alps, 2005, depicts a young African-American "...A young man dressed in military camouflage uniform, Timberland work boots, and a bandana recalls militaristic associations: the genre of historical equestrian portraiture and the violence of modern urban America... Instead of the picturesque landscape background, found in David's painting, Wiley added a decorative, unrealistic background remi- niscent of luxurious French fabric... In addition, the background is filled with images of tiny sperm cells Wiley's way of ridiculing gender stereotypes of masculinity. ... This particular portrait genre, equestrian portrait, is particularly permeated with the origin of male power". [14] Ultimately, Wiley's work, despite its picturesque virtues and deep inner content, is placed among propaganda, and the didactic education of the white part of the population and the return of legal rights to African Americans are its main functions. At the moment, this topic is quite resonant in American culture and affects not only painting but also the media. The video clip - APE$S H I T$, of the duet The Carters (formed by a married couple Beyonce and Jay-Z) [15], is a vivid example. At the moment, the clip has more than 190 million views; the action is developing in the Louvre Museum, in the halls where the pearls of the museum are [16]. Famous $R^{\prime} n^{\prime} B$, pop, hip-hop artists, large media personalities, whose work has great resonance, perform the following lines: "I can't believe that we made it (this is what we made, made) [17] ... This is not yours (no), I don't believe it's yours (no)".

It is in the context of the works of contemporaries and the political situation in the USA of the 200010 s that Alexander Melamid's creative work should be considered. The canvas Fifty Cent, 2005-2008, is of particular interest. On it, the well-known performer is depicted sitting on a chair. In this, you can see an explicit citation of the ceremonial portraits of the rulers and cardinals in the European painting tradition. The musician's body is turned from us, he is sitting on a swivel chair, this gives the picture a feeling of hidden possible dynamics. A sloppy posture and heavy outerwear that he is wearing demonstrate ostentatious negligence. The singer's gaze is casually gliding over the audience as if he is driving a car. A mood of alienation and isolation, reinforced by a shaky, obscure background, is present there; the picture lacks a horizon and there are almost no falling shadows as in the early work Portrait of Albina (ill. 1).

Pablo de Valladolid, a portrait of a buffoon painted by Diego Velazquez in 1636, is the historical prototype of the entire series of portraits of rap artists by Alexander Melamid. The discreet color scheme of the background goes from pearl gray to a deep brown haze, condensing to the edge of the canvas. Only the falling shadow of the model allows us to determine its position in space. The figure is a silhouette without an explicit study of black and white. 
Expressive posture: legs wide apart, pelvis slightly inclined forward, relaxed plastic arms. The model presents himself, not embarrassed by the viewer, and the artist has painted a buffoon, without irony and sarcasm - as if he painted a full-length portrait of an aristocrat. The entire series of Velazquez's portraits of buffoons and dwarfs is filled with respect for the lifestyle of a small man, sympathy, and deep humanism. These same qualities are largely manifested in the works of Alexander Melamid who allows himself an ironic attitude to the model.

However, such irony cannot always be understood by the portrayed person; for example, Fifty Cent uses the portrait by Alexander Melamid as a point of pride in the video clip Fifty Cent - God Gave Me Style [18]. The musician sits on a chair, repeating the composition of Melamid's painting exactly, and the operator chooses the "first-person" perspective, imitating the painter's look. The clip conventionally shows the phased process of portraiture, and the performer sings: "God gave me style, God gave me grace ... But you can't convince me the Lord don't love me" [19]. It is impossible not to note Alexander Melamid's reflection on global changes taking place in the field of art. The classical and the marginal are mixing up, a substitution of concepts is taking place as well as a gradual leveling of generally accepted norms of culture and morality.

The painting Kanye with Friends, 2005-2008, has a completely different character, the portrayed is pictured with modern "symbols of power" [20]; however, they are ironically replaced by half-naked girls. Surrounding their idol on all sides, they are smiling broadly and looking at the viewer. The musician himself is looking the other way, there is no visual contact with him. A similar technique was used by Edouard Manet in The Luncheon on the Grass, 1863. At that time, the painting evoked much public reaction and was not understood, it was accused of rudeness and decadence. Nevertheless, the plot is similar: a naked girl is looking openly at the viewer while men are absorbed in a conversation. It is women who are the main characters in the paintings of Manet and Melamid. The entire series of works by Alexander Melamid is marked by the unity of the color scheme, the dominance of a dark brown background concealing the figures, by es- trangement and isolation of the portrayed. Models defiantly do not notice the artist, engaged in their own business.

In the portrait of Common, we see the same swivel chair on wheels and a relaxed figure of the performer. The singer's gaze is directed beyond the canvas, he is smiling, communicating with someone. The portrait of rapper Snoop Dogg makes the most representative impression, he is absorbed in working at the computer; however, the computer itself is not in the painting, we see only a computer mouse, almost covered by the fingers of the singer. Modern symbols marking the technological revolution and the system of consumption of goods are increasingly penetrating classical painting. Snoop Dogg is the only model from the whole series painted by the artist twice; however, on the second canvas the singer is looking at the viewer, he is relaxed and smiling, sitting in a comfortable leather chair. He is interacting with the viewer and the artist, demonstrating a dismissive gesture known to modern marginal culture.

As in the joint works with Vitaliy Komar, Alexander Melamid's works of the 2000-10s are marked by a citation of world art history and the obvious populism of art expression which is definitely an inertial continuation of the artistic strategy of the duet Komar and Melamid. After analyzing the entire series of portraits of rap artists, we can conclude that Alexander Melamid has remained faithful to the idea of a pictorial installation; out of his paintings, the artist makes a single object that cannot be considered outside the context of the artist's previous work, world art history, and the political and social situation. All works are performed in the same technique, have a similar format, and are an integral conceptual statement.

The purely plastic qualities of the paintings fade into the background. They are not so important for Alexander Melamid - he uses academic painting as a tool to more accurately convey the psychology of the portrayed whom he treats with ironic interest. The painter creates a complex sociocultural space, leaving a large number of explicit and hidden quotes, and they are the main characters in the entire series of paintings. 
1. A popular Moscow cafe, famous for its jazz concerts. It opened during the Thaw period and was the center of creative free-thinking.

2. The cafe regularly hosted exhibitions of contemporary art, the works for which were selected by a special art council.

3. Svetlyakov K. Komar and Melamid: Crushers of Canons. Moscow, 2019. P. 23

4. Alexander Melamid completed his studies at the Stroganov Art College in 1967. The industrial direction of the educational institution was aimed at training in craft and technology; the classic examples of the Renaissance, with layered stages of work, were taken as the basis for painting.

5. Svetlyakov K. Komar and Melamid: Crushers of Canons. Moscow, 2019. P. 20

6. Svetlyakov K. Komar and Melamid: Crushers of Canons. Moscow, 2019. P. 22

7. Vitaly Komar. Three Day Weekend. Cooper Union for Advance of Science and Art, 2005

8. In Emily Foister's article "Eating Souls for Breakfast, Painting Rappers for Lunch" URL: "https://www.vice. com/sv/article/4w8pbj/eating-souls-for-breakfastpainting-rappers-for- lunch (accessed on 9.10.19)

9. In Zinovy Zinik's article "Hip-Hop with Cardinals" URL: https://stengazeta.net/?p=10004829 (accessed on 2.10.19)

10. In the article by Andrei Nikitin, "Russian Artist, Almost a Court Painter 50 Cent" URL: http://www.rap.ru/reading/956 (accessed on 15.10.19)

11. In Zinovy Zinik's article "Hip-Hop with Cardinals"

12. URL: https://stengazeta.net/?p=10004829 (accessed on 2.10.19)
13. "Kehinde Wiley's Global Reach" by Christopher Beam URL: http://nymag.com/arts/art/rules/kehindewiley-2012-4/ (accessed on 23.10.19)

14. It is noteworthy that the artist chose a ceremonial portrait in the classical style and not, for example, the well-known late-romantic painting by Paul Delaroche "Napoleon Crosses the Alps" of 1848-50. In which the unpresentable freezing emperor is depicted on a mule.

15. "Kehinde Wiley Subverts Confederate Monuments with First Public Sculpture in Times Square" By Keith Estiler URL: https://hypebeast.com/2019/10/kehinde-wileyrumors-of-war-sculpture-times-square (accessed on 23.10.19)

16. "Kehinde Wiley, Napoleon Leading the Army over the Alps" by dr. Gayle Clemans. URL: https://smarthistory. org/kehinde-wiley-napoleon-leading-the-army-overthe-alps/ (accessed on 23.10.19)

17. The Carters video resource - APESHIT, URL: https:// www.youtube.com/watch?v=kbMqWXnpXcA (accessed on 23.10.19)

18. Gioconda by Leonardo da Vinci, Venus of Milos, Nika of Samothrace

19. Most likely, these lines are a reference to the fact that the African American population of the United States managed to defend their rights. At this moment, Beyonce and Jay- $Z$ stand against the backdrop of paintings from the era of colonialism in the Louvre.

20. Video resource: 50 Cent - God Gave Me Style. URL: https://www.youtube.com/watch?v=Qlu3UIYxTOU (accessed on 6.11.19)

21. Internet resource. URL: https://textypesen.com/50cent/god-gave-me-style/ (accessed on 5.11.19)

22. In ceremonial portraits, rulers were portrayed with symbols of power: a crown, a scepter, and an orb.

\section{REFERENCES}

1. Tomyuk, O. N. 2020. "Creativity in Martin Heidegger's existentialism", Kul'tura i iskusstvo [Culture and Art], no, 5, pp. 18-26. DOI: 10.7256/2454-0625.2020.5.32811 (in English)

2. Makeeva, S. O. 2019. "Dzhekson Pollok i Allan Kaprou: figura khudozhnika na izlome modernizma", ["Jackson Pollock and Allan Kaprow: the figure of the artist at the break of modernism"] Kul'tura $i$ iskusstvo [Culture and Art], no.11, pp. 45-52. DOI: 10.7256/24540625.2019.11.31584 (in Russian)

3. Jacobi, C., van Atteveldt, W., \& Welbers, K. 2016. "Quantitative analysis of large amounts of journalistic texts using topic modeling", Digital Journalism, vol. 4, no.1, pp. 89-106 DOI: 10.1080/21670811.2015.1093271. (in English)

4. Rutzinskaya, I. I. 2020. "Vystavki k yubileyam Stalina: osobennosti postroyeniya biograficheskogo narrative" ["Exhibitions for the anniversaries of Stalin: fea- tures of the construction of a biographical narrative"], Kul'tura i iskusstvo [Culture and Art], no.1, pp. 1-7. DOI: 10.7256/2454-0625.2020.1.31908 (in Russian)

5. Pyrova, T. L. 2017. "Formirovaniye khip-khop kul'tury: ot sotsial'nogo konteksta do akademicheskogo fenomena" ["The formation of hip-hop culture: from the social context to the academic phenomenon"], Kul'tura $i$ iskusstvo [Culture and Art], no.12, pp. 92-97. DOI: 10.7256/2454-0625.2017.12.23999 (in Russian)

6. Vitaly Komar. Three Day Weekend. 2005. Cooper Union for Advance of Science and Art (in English)

7. Svetlyakov, K. 2019. Komar and Melamid: Crushers of Canons. Moscow (in Russian)

8. Nikitin, A., 2006. "Russkiy khudozhnik - pochti pridvornyy zhivopisets 50 CENT" ["Russian Artist - Almost a Court Painter, 50 CENT"] URL: http://www.rap.ru/reading/956 
9. Orlova, Milena. 2019. "Interview with Alexander Melamid "The Most Important Thing for Me is that I've Taught to Draw Elephants'", [online] The Art Newspaper Russia, Available at: http://www.theartnewspaper. ru/posts/6523/ (accessed on 5 June 2020) (in Russian)

10. Aslanyan, A., 2010. "Bozhestvennaya komediya Aleksandra Melamida" "The Divine Comedy of Alexander Melamid". [online] Radio Liberty. Available at: https:// www.svoboda.org/a/2054162.html (accessed 5 June 2020) (in Russian)

11. Onuchin, M., 2011. "Alexander Melamid's Ministry of Healing by Art", [online] artinvestment.ru. Available at: https://artinvestment.ru/news/artnews/20110527_melamid_clinic.html (accessed on 5 June 2020). (in Russian)

12. Mack, I. 2019. "Artist Alexander Melamid: 'People Spend Money on Art as They Need to Spend it'" [online] Vedomosti. Available at https://www.vedomosti.ru/lifestyle/ characters/2019/03/28/797692-aleksandr-melamid (accessed on 10.16.19) (in Russian)

13. Blagovest-info.ru. 2007. "An American Artist Moved to Rome to Paint 'Human' Portraits of Cardinals". [online] Available at: <http://www.blagovest-info.ru/index. php?id=12457\&s=3\&ss=2> (accessed 12 June 2020). (in Russian)

14. In Zinovy Zinik's article "Hip Hop with Cardinals", [online] Available at: https://stengazeta.net/?p=10004829 (accessed on 2.10.19) (in Russian)

15. Levchenko, L., 2019. How Komar And Melamid Made Contemporary Art Funny. [online] https://www.the-village.ru/, [online] Available at: https://www.the-village. ru/village/weekend/weeknd-interview/349691-komari-melamid (accessed 12 June 2020). (in Russian)

16. "Alex Melamid, Mocad Detroit Holy Hip-Hop!", [online] Available at: https://www.trendhunter.com/trends/holyhip-hop-alexander-melamids-rap-inspired-portraitexhibit (accessed on 5.06.2020)

17. Guseva E., "Alexander Melamid: 'Oh My God'", [online] Available at: https: //artinvestment.ru/news/exhi- bitions/20100526_melamid_at_phillips.html (accessed on 8.10.19) (in Russian)

18. "Alexander Melamid's 'Oh My God' Opens at Phillips de Pury \& Company" [online] Available at: http://artdaily. cc/news/38273/Alexander-Melamid-s - Oh-My-God Opens- at-Phillips-de-Pury -- Company \#.XabQ4ZMzbBI (accessed on 16.10.19) (in Russian)

19. Emily Foister. "Eating Souls for Breakfast, Painting Rappers for Lunch", [online] Available at: "https://www. vice.com/sv/article/4w8pbj/eating-souls-for-breakfastpainting-rappers-for- lunch (accessed on 9.10.19) (in English)

20. Kehinde Wiley studio web site. [online] Available at: http://kehindewiley.com/ (accessed on 5.06.2020) (in English)

21. "Kehinde Wiley's Global Reach" by Christopher Beam. [online] Available at: http://nymag.com/arts/art/ rules/kehinde-wiley-2012-4/ (accessed on 5.06.2020) (in English)

22. By Keith Estiler "Kehinde Wiley Subverts Confederate Monuments with First Public Sculpture in Times Square". [online] Available at: https://hypebeast. com/2019/10/kehinde-wiley-rumors-of-war-sculpturetimes-square (accessed on 23.10.19) (in English)

23. "Kehinde Wiley, Napoleon Leading the Army over the Alps" by dr. Gayle Clemans. [online] Available at: https:// smarthistory.org/kehinde-wiley-napoleon-leading-thearmy-over-the-alps/ (accessed on 23.10.19) (in English)

24. The Carters video resource - APESHIT, [online] Available at: https://www.youtube.com/watch?v=kbMqWXnpXcA (accessed on 23.10.19) (in English)

25. 50 Cent - God Gave Me Style [online] Available at: https://www.youtube.com/watch?v=Qlu3UIYxTOU (accessed on 6.11.19) (in English)

26. The words of the song God Gave Me Style. [online]. Available at: https://textypesen.com/50-cent/godgave-me-style/ (accessed on 5.11.19) (in English) 
доцент кафедры «История искусства и гуманитарные дисциплины» Московской государственной художественно-промышленной академии им. С.Г. Строганова e-mail: logomachia@mail.ru

Россия, Москва

ORCID 0000-0003-4950-3891

ResearcherID AAH-2163-2020

Александра Михайловна Спиридонова

аспирант кафедры «История искусства и гуманитарные дисциплины» Московской государственной художественно-промышленной академии им. С. Г. Строганова e-mail: freaklt@yandex.ru

Россия, Москва

ORCID 0000-0003-2760-8553

ResearcherID AAH-2166-2020

DOI: 10.36340/2071-6818-2020-16-2-33-46

\section{ПОРТРЕТНАЯ ЖИВОПИСЬ АЛЕКСАНДРА МЕЛАМИДА 2010-Х ГОДОВ}

Аннотация. Статья посвящена комплексному исследованию портретной живописи Александра Меламида, вошедшей в его первый самостоятельный проект после тридцати лет совместного творчества с Виталием Комаром. Живописцы на протяжении всего тридцатилетнего периода сотрудничества подписывали свои работы товарным знаком «Комар и Меламид», что усложняет возможность определения индивидуального характера художников. Представлен подробный анализ сольных работ 60-70-х годов, до начала совместного творчества. Он помогает нам выявить индивидуальные черты в произведениях дуэта и лучше идентифицировать личности авторов, реконструировать технические особенности живописи каждого художника.

В 2007 году Александр Меламид начнёт писать крупномасштабную серию полотен, которая станет его новой концептуальной линией творчества. Позже, в 2009 году, художник разовьёт и дополнит эту серию портретами итальянских священнослужителей и русских олигархов. В статье рассматриваются характерные признаки портретной серии «Святой хип-хоп!», экспо- нированной в Музее современного искусства в Детройте в 2008 году. Художник уделял особое внимание психологическим характерам портретируемых. Вся серия написана в одной цветовой гамме, в одном масштабе полотен. Живописная серия является цельным концептуальным высказыванием. Сугубо пластические качества полотен отходят на второй план. Они не так важны для Александра Меламида - он использует академическую живопись как инструмент, позволяющий более точно передать психологию портретируемых, к которым он относится с ироничным интересом. Важно отметить, что Александр Меламид стирает грань между классическим и маргинальным искусством, так же как это делал в своё время Франсуа Милле.

В статье удалось обновить социокультурную проблематику благодаря контекстному сравнению с портретной живописью Диего Веласкеса и современным американским художником Кехинде Уайли, чья творческая жизнь глубоко интегрирована в социально-политические реалии США начала XXI века и афроамериканскую культурную традицию. Кехинде Уайли известен своими реалистичными крупномас- 
штабными изображениями афроамериканцев в позах, заимствованных из произведений классической европейской живописи XVII-XIX веков. Художник открыто пропагандирует, нарочито подчёркивая дидактическую функцию своих полотен. Именно в контексте работ современников и политической ситуации в США

Основной задачей научного исследования в данной статье является осмысление творческой эволюции Александра Меламида, который более тридцати лет работал в дуэте с Виталием Комаром. Художники на протяжении всего периода сотрудничества совместно подписывали свои работы, редко давая комментарии по поводу распределения обязанностей или процесса создания картин. Именно анализ сольных работ 60-70-х годов, до начала совместного творчества, и период с 2003 года (год распада группы) помогает нам выявить индивидуальные черты в произведениях дуэта и лучше идентифицировать личности художников.

Совместный период творчества художников начался в 1970-х годах, и их ранние персональные работы представлены очень мало, так как почти все были вывезены за рубеж. Полотна впоследствии вернулись в Россию, но сейчас находятся в частных собраниях. Первые их выставки проходили в кафе «Синяя птица» [1]. Один из ведущих исследователей творчества художников Кирилл Светляков пишет: «Если попытаться провести различия в подходах Комара и Меламида, то можно предположить, что Комар больше увлекался психологией стилей, а Меламид - психологией восприятия» [2]. Одним из ярких примеров ранней живописи Александра Меламида является полотно 1969 года «Портрет Альбины» (ил. 1). Работа выполнена в манере alla prima: сквозь резкие холодные мазки фона просвечивает охристый грунт, свидетельствующий о знании классической технологии масляной живописи [3]. Изображение модели мало взаимодействует со зрителем и пространством вокруг себя. Композиция отличается некоторой небрежностью: колени обрезаны краем холста, руки не прописаны. Образ психологически заострён - выражение лица сумрачно и депрессивно, о чём свидетельствуют резко очерченные веки. Это не любование человеческим естеством и природой бытия, а скорее болезненная констатация фактов действительности, с большой долей вероятности цитирование образов обитателей парижского дна А.Д. Тулуза-Лотрека, которые, наряду с другими нулевых - десятых годов нужно рассматривать творчество Александра Меламида.

Ключевые слова: Комар и Меламид, соц-арт, Александр Меламид, Виталий Комар, портретная живопись, Кехинде Уайли.

немногочисленными работами представителей западной модернистской живописи, были знакомы советскому зрителю благодаря издательской деятельности журнала «Знание - сила», редакторы которого являлись постоянными посетителями выставок и концертов в кафе «Синяя птица» [4]. В работе «Портрет Альбины» присутствуют художественные приёмы, позднее проявившиеся в индивидуальной манере художника с 2007 года. На полотне нет ярко выраженной линии горизонта; фигура повисает в пространстве воздуха; плотная гамма сдержанных тонов, в которой доминируют глубокие коричневые и зеленоватые оттенки, поддерживает общее тяжеловесное настроение полотна. Именно к такой формуле композиционного повествования вернётся Александр Меламид после тридцатилетнего периода совместного творчества. Позже художник даст комментарии к своим ранним работам, называя их: ««периодом абсолютной правды» по отношению к ироническим играм следующего десятилетия [5]».

«Портретный период» начнётся у Александра в 2006 году - через три года после распада дуэта, - и если Виталий Комар в это время пойдёт по пути поиска внутренней национальной идентичности, возврата к детству, рефлексии на тему совместного творчества [6], то Александр Меламид после трёхлетнего творческого затишья начинает вести новую концептуальную живописную линию. Художник начинает писать масштабную серию портретов рэперов в 2007 году. Затем переключает своё внимание на кардиналов и служителей итальянских монастырей, а позднее, в 2009 году, - на портреты русских олигархов. В 2010 году все портретные серии объединяются в общей концепции выставки «Oh My God», на презентации которой художник заявляет: «Будучи Богом, я являюсь создателем всего на свете, включая обычные объекты, такие как камни и прочее, поэтому я стараюсь охватить все основы. Важно то, что я создаю этих людей. Они не существуют без меня. Я поднимаю их и ставлю на пьедестал» [7].

Александр Меламид комментирует поворот в своём творчестве в статье Зиновия Зиника: 
«На каком-то этапе своей жизни я задумался над тем, что мне делать дальше. Или вернуться в ностальгическое прошлое - родители, детство, воспоминания, - или идти куда-то вперёд. Но куда? И тут я понял, что мой сын - он как раз и ушёл дальше. Дальше от нашего общего прошлого, от Москвы как Третьего Рима, от проблемы Востока и Запада и так далее» [8]. Сын художника Денис Меламид работает на всемирно известном лейбле G-Unit в должности звукорежиссёра и участвует в производстве видеоклипов. Его имя фигурирует как «Dan «The Man» Melamid» [9].

Меламид осознанно дистанцируется от изображаемой натуры; культурные различия и особенности воспитания не позволяют художнику быть глубоко интегрированным в новую музыкальную среду. Он комментирует: «Это на самом деле культ белых детей богатых родителей. Для них рэперы - некий сказочный идеальный мир. Мы все мечтали в детстве, как у Набокова мальчики, убежать в Америку. В русском лесу в Кратово. Мы убегали в лес, как в Америку. Это мир немыслимой свободы, где людей, конечно, убивают, но зато ты не должен учить латынь и арифметику, или изучать музыку Баха и Чайковского». Но затем художник добавляет для соблюдения политкорректности: «...рэперы... известны своим поклонникам, своему окружению, а те ничего не понимают в живописи. Те же, кто понимает в живописи, вряд ли слышали про рэперов. Я их соединяю вместе. Это загадочный мир. Он мне любопытен. Что ещё есть вообще на свете, кроме живого любопытства?» [10].

Для Александра Меламида, живущего в Америке с 1978 года, социальный контекст, создаваемый расовыми конфликтами, риторикой толерантности и ростом национализма, является повседневной действительностью. Политика и культура проникают в жизнь и творчество точно так же, как и советская визуальная пропаганда постоянно сопровождала жизнь советского человека в молодости художника. Создание соц-арта как реакции и анализа политической пропаганды было творческим высказыванием художников, с помощью которого они транслировали идеи в общественное сознание. К такому же приёму обращается Меламид, работая над серией портретов рэперов. Они - не просто частное художественное высказывание, в котором можно увидеть самоцитирование серии «Ностальгический соцреализм» 1981-1982 годов, оммаж бароч- ной живописи XVII века или прямое подражание серии карликов и шутов Диего Веласкеса 1630$1640-x$ годов. Это живопись, которая не может существовать без контекста произведений художников - современников Меламида, искусство которых носит более политизированный характер.

Сложно избежать сравнения портретной живописи Александра Меламида с работами живущего в Нью-Йорке нигерийско-американского художника Кехинде Уайли (Kehinde Wiley), известного своими реалистичными крупномасштабными изображениями афроамериканцев в позах, заимствованных из произведений классической европейской живописи XVII-XIX веков. Уайли известен декоративным приёмом - реалистично трактованные модели всегда находятся на фоне, богато украшенном растительным орнаментом, основанным на мотивах больших стилей прошлого: Возрождения, барокко, ампира. Серия картин Уайли 2006-2007 годов «Слухи войны» представляет для нас наибольший интерес. В ней художник «переносит людей в контексты военной славы» [11], так как она хронологически совпадает с началом портретного периода Александра Меламида. Прототипом одной из картин Кехинде Уайли стало знаменитое полотно крупнейшего представителя французской живописи Жака-Луи Давида «Бонапарт на перевале СенБернар» (1801), работавшего в неоклассическом стиле [12]. Кехинде Уайли категорично высказывает свою позицию взаимодействия афроамериканского и европейского искусства: «Искусство и насилие вечно противостояли друг другу. «Слухи о войне» пытаются использовать композиционные особенности конного портрета, чтобы осветить проблему и обратить внимание общественности на фетишизацию насилия со стороны государства... Я считаю, что, когда художник работает с историей, с неоднозначным прошлым и, возможно, сомнительно прекрасным будущем, он должен использовать все средства, имеющиеся в его распоряжении. То, что я пытаюсь сделать, это сказать «да» некоторым аспектам истории. И я говорю «нет» другим» [13].

На картине Уайли «Наполеон ведёт армию через Альпы» (2005) (ил. 3) изображён молодой афроамериканец. «...Молодой человек, одетый в военную камуфляжную униформу, рабочие ботинки Timberland и бандану, вызывает в памяти милитаристические ассоциации: жанр исторического конного портрета и насилие современной 
урбанистической Америки... Вместо живописного пейзажного фона, присутствующего на картине Давида, Уайли добавил декоративный, нереалистичный фон, напоминающий роскошную французскую ткань... Кроме того, фон наполнен изображениями крошечных сперматозоидов - способ Уайли высмеять гендерные стереотипы мужественности [14]... Этот особый жанр портрета — конный портрет - особенно пронизан происхождением мужской силы» [14]. В конечном итоге творчество Уайли, несмотря на свои живописные достоинства и глубокое внутреннее наполнение, становится в один ранг с пропагандой, и его главная функция - дидактическое воспитание белокожей части населения и возвращение законных прав афроамериканцам. На данный момент эта тема достаточно резонансна в американской культуре и затрагивает не только живопись, но и медиа. Ярким примером является видеоклип дуэта The Carters (образованного супружеской парой Бейонсе и Джей-Зи (Beyonce and Jay-Z)) «APESHIT» [15]. На данный момент у клипа более 190 млн просмотров. Действие развивается в Лувре, в залах, где представлены жемчужины музея [16], известные R'n'B-, поп-, хип-хоп-исполнители, крупные медийные личности, творчество которых имеет огромный резонанс, исполняют следующие строки: «Я не могу поверить, что мы сделали это (мы сделали это, сделали) [17]... Это не ваше (нет), Я не думаю, что это ваше (нет)».

Именно в контексте работ современников и политической ситуации в США нулевых - десятых годов нужно рассматривать творчество Александра Меламида. Особый интерес вызывает полотно «Fifty Cent». 2005-2008 годов. На нём известный исполнитель изображён сидящим на стуле, в чём можно усмотреть явное цитирование парадных портретов правителей и кардиналов европейской живописной традиции. Корпус музыканта отвёрнут он нас. Он расположился на вращающемся стуле - это придаёт картине ощущение скрытой возможной динамики. Небрежная поза и неснятая тяжёлая верхняя одежда демонстрируют показную небрежность. Взгляд певца мимоходом скользит по зрителям - так, как если бы он проезжал мимо на автомобиле. Присутствует настроение отчуждённости и замкнутости, усиленное зыбким неясным фоном. На картине отсутствует линия горизонта и почти нет падающих теней, так же как и в ранней работе «Портрет Альбины» (ил. 1).
«Пабло де Вальядолид» - портрет шута, написанный Диего Веласкесом в 1636 году, - выступает историческим прототипом всей серии портретов рэп-исполнителей Александра Меламида. Сдержанная цветовая гамма фона переходит от жемчужно-серого в насыщенно-коричневое марево, уплотняющееся к краю полотна. Только падающая от портретируемого тень позволяет нам определить его положение в пространстве. Фигура решена силуэтно, без явной проработки светотеневых отношений. Выразительная поза: широко раздвинутые ноги, немного наклонённый вперёд таз, расслабленные пластичные руки. Модель презентует себя, не стесняясь зрителя, а художник пишет шута без иронии и сарказма так, как если бы он писал парадный портрет аристократа. Вся серия портретов шутов и карликов Веласкеса наполнена уважением к образу жизни маленького человека, сочувствием и глубоким гуманизмом. Эти же качества в значительной мере проявляются и в работах Александра Меламида, однако, позволяющего себе ироничное отношение к модели.

Но такая ирония не всегда может быть считана портретируемым - так, например, 50 Cent использует портрет, написанный Александром Меламидом, как предмет гордости в клипе «50 Cent - God Gave Me Style» [18]. Музыкант восседает на стуле, точно повторяя композицию картины Меламида, причём оператор выбирает ракурс «от первого лица», имитируя взгляд живописца. В клипе условно показан поэтапный процесс написания портрета, и исполнитель поёт: «Бог дал мне стиль, Бог дал мне благодать... Но вы не можете убедить меня, что Господь не любит меня» [19]. Невозможно не отметить рефлексию Александра Меламида на глобальные изменения происходящие в сфере искусства. Классическое и маргинальное смешивается, происходит подмена понятий и постепенное нивелирование общепринятых норм культуры и морали.

Холст «Канье с друзьями» 2005-2008 годов несёт в себе совершенно другой характер. В нём портретируемый изображён с «символами власти», но они иронично заменены на полуобнажённых девушек. Окружая своего кумира со всех сторон, они широко улыбаются и смотрят на зрителя. Сам музыкант смотрит в сторону - с ним не возникает визуального контакта. Подобный приём использовал Эдуар Мане в картине «Завтрак на траве» 1863 года. На тот момент картина вызвала 
широкий резонанс и была не понята публикой, обвинена в грубости и декадансе. Но фабула сюжета схожа: обнажённая девушка открыто смотрит на зрителя, в то время как мужчины увлечены беседой. Именно женщины в картинах Мане и Меламида выступают главными действующими лицами полотен. Весь цикл работ Александра Меламида отмечен единством цветовой гаммы, господством тёмно-коричневого фона, скрадывающего фигуры, отрешённостью и изолированностью портретируемых. Модели демонстративно не замечают художника, занимаясь своими делами.

В портрете Коммона (Common) мы видим всё тот же вращающийся стул на колёсиках и расслабленную фигуру исполнителя. Взгляд певца направлен за пределы полотна, он улыбается, общаясь с кем-то. Потрет рэпера Снуп Дога (Snoop Dogg) производит наиболее репрезентабельное впечатление: он поглощён работой за компьютером, но самой ЭВМ нет на полотне - мы видим только компьютерную мышь, почти прикрытую пальцами певца. В классическую живопись всё больше проникают современные символы, маркирующие технологическую революцию и систему потребления товаров. Снуп Дог - единственная модель из всего цикла, написанная художником дважды, но на втором полотне певец смотрит на зрителя, он расслаблен и улыбается, сидя в удобном кожаном кресле. Он взаимодействует со зрителем и художником, демонстрируя известный современной маргинальной культуре пренебрежительный жест.

Как и в совместных работах с Виталием Комаром, произведения Александра Меламида нулевых-десятых годов отмечены цитированием мировой истории искусства и явным популизмом художественного высказывания, что определённо является инерционным продолжением художественной стратегии дуэта «Комар и Меламид». Проанализировав весь цикл портретов рэп-исполнителей, можно прийти к выводу, что Александр Меламид остался верным идее живописной инсталляции. Художник делает из своих живописных серий единый объект, который невозможно рассматривать вне контекста предыдущего творчества художника, мировой истории искусств, политической и социальной обстановки. Все работы выполнены в одной технике, имеют схожий формат и являются цельным концептуальным высказыванием.

Сугубо пластические качества полотен отходят на второй план. Они не так важны для Александра Меламида - он использует академическую живопись как инструмент, позволяющий более точно передать психологию портретируемых, к которым он относится с ироничным интересом. Живописец создаёт сложное социокультурное пространство, оставляя большое количество явных и скрытых цитат, и именно они являются главными героями всей живописной серии.

\section{ПРИМЕЧАНИЯ}

1. Популярное московское кафе, известное своими джазовыми концертами, открывшееся в период «оттепели» и бывшее центром творческого свободомыслия.

В кафе регулярно проходили выставки современного искусства, отбор произведений для которых осуществлял специальный художественный совет.

2. Светляков К. Комар и Меламид: сокрушители канонов. М., 2019. С. 23.

3. Александр Меламид окончил в 1967 году Строгановское художественное училище.

4. Светляков К. Комар и Меламид: сокрушители канонов. М., 2019. С. 20.

5. Светляков К. Комар и Меламид: сокрушители канонов. М., 2019. С. 22.

6. Vitaly Komar. Three Day Weekend. Cooper Union for Advance of Science and Art. 2005.
7. В статье EMILY FOISTER «Eating Souls for Breakfast, Painting Rappers for Lunch» URL: https://www.vice. com/sv/article/4w8pbj/eating-souls-for-breakfastpainting-rappers-for-lunch (дата обращения: 28.05.2020).

8. В статье Зиновия Зиника «Хип-хоп с кардиналами» URL: https://stengazeta.net/?p=10004829 (дата обращения: 28.05.2020).

9. В статье Андрея Никитина «Русский художник почти придворный живописец 50 Cent» URL: http://www.rap.ru/reading/956 (дата обращения: 28.05.2020).

10. В статье Зиновия Зиника «Хип-хоп с кардиналами»

11. URL: https://stengazeta.net/?p=10004829 (дата обращения: 28.05.2020).

12. Примечательно, что художник выбрал парадный потрет в классическом стиле, а, например, не хорошо известную позднеромантичсекую картину Поля 
Делароша «Наполеон пересекает Альпы» 18481850 годов, на которой непрезентабельный замерзающий император изображён верхом на муле.

13. «Kehinde Wiley Subverts Confederate Monuments with First Public Sculpture in Times Square» By Keith Estiler URL: https://hypebeast.com/2019/10/kehinde-wileyrumors-of-war-sculpture-times-square (дата обращения: 28.05.2020).

14. «Kehinde Wiley, Napoleon Leading the Army over the Alps» by dr. Gayle Clemans URL: https://smarthistory. org/kehinde-wiley-napoleon-leading-the-army-overthe-alps (дата обращения: 28.05.2020).

15. Видеоресурс The Carters - APESHIT, URL: https:// www.youtube.com/watch?v=kbMqWXnpXcA (дата обращения: 28.05.2020).
16. Джоконда Леонардо да Винчи, Венера Милосская, Ника Самофракийская.

17. Скорее всего, эти строки - отсылка к тому, что афроамериканскому населению США удалось отстоять свои права. Бейонсе и Јау-Z в этот момент стоят в Лувре на фоне картин эпохи колониализма.

18. Видеоресурс 50 Cent - God Gave Me Style URL: https://www.youtube.com/watch?v=Qlu3UIYxTOU (дата обращения: 28.05.2020).

19. Интернет-ресурс URL: https://textypesen.com/ 50-cent/god-gave-me-style (дата обращения: 28.05.2020).

\section{БИБЛИОГРАФИЯ}

1. Tomyuk, O. N. 2020. Creativity in Martin Heidegger's existentialism // Культура и искусство.- - no. 5, pp. 18-26. DOI: 10.7256/2454-0625.2020.5.32811

2. Макеева С.О.- Джексон Поллок и Аллан Капроу: фигура художника на изломе модернизма // Культура и искусство. - 2019. - № 11. - С. 45-52. DOI: 10.7256/2454-0625.2019.11.31584 URL: https:// nbpublish.com/library_read_article.php?id=31584

3. Jacobi, C, van Atteveldt, W, Welbers, K. 2016. "Quantitative analysis of large amounts of journalistic texts using topic modeling», Digital Journalism, vol. 4, no.1, pp. 89-106 DOI: 10.1080/21670811.2015.1093271.

4. Руцинская И.И. 2020. Выставки к юбилеям Сталина: особенности построения биографического нарратива // Культура и искусство. - no, pp. 1-7. DOI: 10.7256/2454-0625.2020.1.31908

5. Пырова Т.Л. 2017. Формирование хип-хоп культуры: от социального контекста до академического феномена // Культура и искусство. - no. 12, рр. 92-97. DOI: 10.7256/2454-0625.2017.12.23999

6. Vitaly Komar. Three Day Weekend. Cooper Union for Advance of Science and Art. 2005.

7. Светляков К. Комар и Меламид: сокрушители канонов. М., 2019.

8. В статье Андрея Никитина «Русский художник - почти придворный живописец 50 CENT» URL: http:// www.rap.ru/reading/956 Журнал XXL (дата обращения: 28.05.2020).

9. Орлова М. «Александр Меламид: „Самое важное для меня - что я научил рисовать слонов"» URL: http://www.theartnewspaper.ru/posts/6523 (дата обращения: 28.05.2020).

10. Асланян А. «Божественная комедия Александра Меламида» URL: https://www.svoboda.org/a/2054162. html (дата обращения: 28.05.2020).

11. Онучина М. «"Министерство Исцеления Искусством“ Александра Меламида» URL: https://artinvestment.ru/ news/artnews/20110527_melamid_clinic.html (дата обращения: 28.05.2020).
12. Мак И. «Художник Александр Меламид: „Люди тратят деньги на искусство, потому что надо их истратить"» URL: https://www.vedomosti.ru/lifestyle/ characters/2019/03/28/797692-aleksandr-melamid (дата обращения: 28.05.2020).

13. Электронный ресурс «Американский художник приехал в Рим, чтобы писать „человеческие“ портреты кардиналов» URL: http://www.blagovest-info.ru/ index.php?id=12457\&s=3\&ss=2 (дата обращения: 28.05.2020).

14. Зиновй Зиник «Хип-хоп с кардиналами» URL: https://stengazeta.net/?p=10004829 (дата обращения: 28.05.2020).

15. Левченко Л. «Как Комар и Меламид сделали современное искусство смешным» URL: https://www. the-village.ru/village/weekend/weeknd-interview/ 349691-komar-i-melamid (дата обращения: 28.05.2020).

16. Видеоресурс: URL: https://www.trendhunter.com/ trends/holy-hip-hop-alexander-melamids-rapinspired-portrait-exhibit (дата обращения: 28.05.2020).

17. Гусева Е. «Александр Меламид: „Oh My God”» URL: https://artinvestment.ru/news/exhibitions/20100526_ melamid_at_phillips.html (дата обращения: 28.05.2020).

18. Emily Foister «Eating Souls for Breakfast, Painting Rappers for Lunch» URL: https://www.vice.com/sv/ article/4w8pbj/eating-souls-for-breakfast-paintingrappers-for-lunch (дата обращения 28.05.2020).

19. Интернет-ресурс URL: http://kehindewiley.com (дата обращения 28.05.2020).

20. «Kehinde Wiley's Global Reach» By Christopher Beam URL: http://nymag.com/arts/art/rules/kehindewiley-2012-4 (дата обращения: 28.05.2020).

21. Keith Estiler. «Kehinde Wiley Subverts Confederate Monuments with First Public Sculpture in Times Square» URL: https://hypebeast.com/2019/10/kehindewiley-rumors-of-war-sculpture-times-square (дата обращения: 28.05.2020). 
22. «Kehinde Wiley, Napoleon Leading the Army over the Alps» by dr. Gayle Clemans URL: https://smarthistory. org/kehinde-wiley-napoleon-leading-the-army-overthe-alps (дата обращения: 28.05.2020).

23. Видеоресурс The Carters - APESHIT, URL: https:// www.youtube.com/watch?v=kbMqWXnpXcA (дата обращения: 28.05.2020).
24. Видеоресурс 50 Cent - God Gave Me Style URL: https://www.youtube.com/watch?v=Qlu3UIYxTOU (дата обращения: 28.05.2020). 